\title{
Selection of (Deli $\times$ Angola Novo-Redondo) Selfed × La Mé Progenies for Improved Oil Palm Productivity
}

\author{
Benjamin Adon ${ }^{1}$, Claude Bakoumé ${ }^{2}$, Jean Noel Konan ${ }^{1}$, Sekou Diabaté ${ }^{1}$, Benoît Cochard ${ }^{3}$, \\ Anatole Koutou ${ }^{1} \&$ Didier Paulin Sokouri ${ }^{4}$ \\ ${ }^{1}$ CNRA Station Principale de La Mé, Abidjan, Côte d'Ivoire \\ ${ }^{2}$ Maxi Productivity Sarl, Douala, Cameroon \\ ${ }^{3}$ CIRAD-CP, Montpellier, France \\ ${ }^{4}$ Felix Houphouet-Boigny University, Abidjan, Côte d'Ivoire \\ Correspondance: Benjamin Adon, CNRA Station Principale de La Mé 13 BP 989, Abidjan 13, Côte d'Ivoire. Tel: \\ 225-0734-8099/0861-8230. E-mail: benjamin_adon@yahoo.fr
}

Received: October 7, 2021

doi:10.5539/jas.v13n12p51
Accepted: November 1, 2021

Online Published: November 15, 2021

URL: https://doi.org/10.5539/jas.v13n12p51

\begin{abstract}
Introgression of Angola Novo-Redondo origin into the Deli origin was achieved for the first time in Côte d'Ivoire. Unfortunately, the genetic variability of (Deli $\times$ Angola Novo-Redondo) genitors selected was a challenge facing seed production. The best (Deli $\times$ Angola Novo-Redondo) genitor LM $5448 \mathrm{~T}$ was selfed expecting more stable genotypes for improved oil palm productivity. (Deli $\times$ Angola Novo-Redondo) selfed $\times$ La Mé progenies were planted at Ehania in Côte d'Ivoire. At maturity, they presented 8\% rise over the controls' mean $\left(155.72 \mathrm{~kg} \mathrm{palm}^{-1} \mathrm{yr}^{-1}\right)$ for total bunch weight (TBW). ANOVA revealed difference between (Deli $\times$ Angola Novo-Redondo) selfed genitors for bunch production, vertical growth rate, and bunch characteristics. DMRT showed that progenies overlapped each other indicating their genetic resemblance, a feature supported by the low CV values (3-8\%) of all the parameters measured. Progenies LM 22723, LM 22835, and LM 23169 whose increase over controls' means for TBW and bunch number were $11 \%$ and $12 \%$, respectively, and whose mean Fusarium index was 56 should be selected for commercial seed production. Estimated breeding values of LM 15516 D and LM 15311T, Group A parents of the 3 progenies would help predicting planting materials' performances.
\end{abstract}

Keywords: bunch production, bunch characteristics, breeding value, oil yield, seed production

\section{Introduction}

Oil palm (Elaeis guineensis Jacq.) is a perennial plant species found in wild or subspontaneous form in African rainforests. The plant is cultivated for the oil extracted from the mesocarp and kernel of the fruit (Hartley, 1988) for food and non-food uses. Friends of the Earth (2018) reported, after an assessment of global palm oil consumption, that $71 \%$ of palm oil is for food (e.g., cooking oil, margarine, processed foods, and chocolate), $24 \%$ for consumer products (e.g., cosmetics, detergents, candles) and 5\% for energy (electricity, heating, fuels). In fact, palm oil demand is a function of both the growing increase in food and non-food uses and in world population. In 2018, the African population reached 1.215 billion. One of the factors that contributes to a sustainable increase in Africa's population is the considerable fight against common and endemic diseases. Better preventive measures developed to limit the incidence of human immunodeficiency virus (HIV) and malaria led to a sustainable increase in the continent's population (Bakoumé et al. 2018). In 2018, the continent's demand for oil and fats was estimated at 30.64 million tons (Bakoumé et al. 2018). Oil production accounted for about $8 \%$ of the demand (2.434 million tons). The use of high yielding plant material coupled with best management practices is essential to meet this growing demand for palm oil. This involves opting for the tenera oil palm, a hybrid $\left(\mathrm{sh}^{+} / \mathrm{sh}^{-}\right)$resulting from a cross between the dura, homozygous $\left(\mathrm{sh}^{+} / \mathrm{sh}^{+}\right)$with a thick shell of more than 2 $\mathrm{mm}$, and the pisifera, homozygous $\left(\mathrm{sh}^{-} / \mathrm{sh}^{-}\right)$without a shell. In fact, the tenera type produces at least $25-30 \%$ more palm oil than the dura type. Pisifera has generally sterile and abortive female inflorescences (Bakoumé, 2016). 
Since the early 1900s, genetic improvement of local populations through phenotypic mass selection has been initiated to increase the productivity of palm plantations. Unfortunately, the yield increment from mass selection was very low (Bakoumé et al. 2016). Oil palm research in Côte d'Ivoire has adopted the reciprocal recurrent selection (RRS) scheme. This scheme simultaneously improves Deli origins (Group A) made up of dura palms and African origins (Group B) of pisifera and tenera palms. The two cycles of RRS completed from 1960 to 1995 led to more than $36 \%$ oil yield increase compared to the first inter-origin progenies (Gascon et al., 1988). Climatic changes induced by deforestation has resulted in pronounced drought spell in Africa including Côte d'Ivoire. Few consequences for oil palm agriculture include yield depression, planting of new areas (more deforestation) for more palm oil production, and early replanting of oil palm fields with tall palms. Furthermore, moving oil palm seedlings from one area to another has favoured the dispersal of Fusarium wilt all over the oil palm distribution area in Africa including Côte d'Ivoire. Fusarium wilt also known as fusariose in Africa is caused by Fusarium oxysporum f.sp. elaeidis, a soil-borne fungal pathogen. The disease either kills infected palms or enfeebles the plant. In infected oil palm field, more than 50\% of the palms can be lost (Bakoumé, 2016). Therefore, new challenges facing oil palm research and oil palm development in Côte d'Ivoire and Africa as well are the increase or at least stabilization of palm oil yield potential of planting materials, extension of the economic life of oil palm fields and control of Fusarium wilt. The ultimate mitigation measure to the above-mentioned challenges for oil palm research are breeding for palm oil yield increment or stability, slow oil palm growth rate, and crop tolerance to Fusarium wilt.

Breeding is a genetic adjustment of plants to social, cultural, economic, technological and environmental aspects (Chaudhary, 1984). In Côte d'Ivoire, breeding in oil palm is at its third cycle. In plants, including oil palm, the significant improvement in yield has been accompanied by a drastic reduction in the genetic base of the parent material because of severe phenotypic choices. In the oil palm breeding scheme in Côte d'Ivoire, only five palms selected from a survey carried out in the Bingerville region including the botanical gardens and the Bingerville wild palm grove were represented in the La Mé population (Cochard et al., 2000) until the end of the last century. The latter was the sole source of all Group B male genitors for commercial seed production. The narrow genetic base of the La Mé origin led to the enrichment of Group B with Sibiti origin, among few others. On the other hand, Group A is represented by the Deli origin only. Furthermore, all oil palm seeds supplied to farmers in Côte d'Ivoire are derived from less than a dozen Deli dura, which are female parents of tenera hybrids. Broadening of the genetic base of Group A of Deli dura using Angola origin was anticipated in 1971 with the introduction of 6 selected oil palm genitors from the Angolan natural palm groves of Novo-Redondo (3 genitors) and Salazar (3 genitors). Previous works in Group A showed considerable bunch and oil productions and relatively high tolerance to Fusarium wilt of (Deli $\times$ Angola) $\times$ La Mé progenies. Furthermore, they revealed a high variability within the progenies of Deli $\times$ Angola crosses for bunch and oil yield and their components and height growth (Adon, 1995).

In the present study, (Deli $\times$ Angola Novo-Redondo) genitor LM $5448 \mathrm{~T}$, the best among those tested in at a previous stage (Adon et al., 2021), was self-pollinated (selfed) to produce (Deli $\times$ Angola Novo-Redondo) selfed descendants crossed with La Mé and Sibiti $\times$ La Mé testers. The trial EH GP3 has evaluated (Deli $\times$ Angola Novo-Redondo) selfed $\times$ La Mé and (Deli $\times$ Angola Novo-Redondo) selfed $\times($ Sibiti $\times$ La Mé) progenies to select the most stable (Deli $\times$ Angola Novo-Redondo) selfed genotypes for bunch and oil yields, slow vertical growth rate, and tolerance to Fusarium wilt for the production of commercial seeds for oil palm growers.

\section{Materials and Methods}

\subsection{Plant Material}

A total of 27 genitors were used in the progeny trial. Group A was represented by 15 genitors, including 10 from LM 5448 T selfed (4 tenera, 3 dura, and 3 pisifera), 4 Deli dura selected in Dabou (Côte d'Ivoire), and LM 5448 $\mathrm{T}$, a descendant of a (Deli $\times$ Angola Novo-Redondo) cross. Group B involved 12 genitors of which 10 belonged to the La Mé origin (Côte d'Ivoire), including 7 dura and 3 tenera, and 2 dura genitors descendants of the intra-group cross (Sibiti $\times$ La Mé) produced at La Mé. 25 progenies from (Group A $\times$ Group B) crosses were produced including 19 progenies from (Deli $\times$ Angola Novo-Redondo) selfed $\times$ La Mé crosses, 3 [(Deli $\times$ Angola Novo-Redondo) selfed $\times($ La Mé $\times$ Sibiti)] crosses, and 3 (Deli $\times$ La Mé) crosses (Table 1). The 3 progenies from (Deli $\times$ La Mé) crosses were trial controls. The crossing design was a North Carolina II (NC II). The genetic trial was established at Ehania in 2002. Ehania is located in the southeast of Côte d'Ivoire, $140 \mathrm{~km}$ from Abidjan, in the Aboisso Division. The climate is sub-equatorial, characterized by 4 seasons i.e. 2 rainy seasons and 2 dry seasons. The annual rainfall is $1700-2200 \mathrm{~mm}$. The average annual temperature is $22-31{ }^{\circ} \mathrm{C}$ and the relative humidity is estimated at $80 \%$. The average annual sunshine is estimated at 1800 hours. The soils vary in texture from sandy-clay with more than $15 \%$ of fine elements to clayey with less than $80 \%$ of clay. The 
soils are deep and the $\mathrm{pH}$ is between 4.5 and 7. The original vegetation was a dense forest (Coulibaly, 2001). The experimental design is a $5 \times 5$ balanced lattice with 6 replicates and 16 trees per elementary plot. The planting density was 143 trees per hectare arranged in an equilateral triangle of $9 \mathrm{~m}$ side.

Table 1. Details of oil palm progeny trial EH GP3 planted at Ehania (Côte d'Ivoire)

\begin{tabular}{|c|c|c|c|}
\hline Progeny number in the trial & Progeny & Cross & Inter-group combination type \\
\hline 1 & - & $L M 2 T \times \underline{\text { DA } 10 \mathbf{D}}$ & La Mé $\times$ Deli* \\
\hline 2 & LM 24077 & $L M 2 T \times \underline{\mathbf{D A} 115 \mathbf{D}}$ & La Mé × Deli* \\
\hline 3 & LM 22412 & $L M 5476 \mathrm{D} \times \mathrm{LM} 5448 \mathrm{~T}^{* *}$ & La Mé $\times($ Deli $\times$ Angola Novo-Redondo $)$ \\
\hline 4 & LM 21983 & $L M 2448 T \times \underline{\mathbf{L M} 2536 \mathbf{D}}$ & La Mé × Deli* \\
\hline 5 & LM 22991 & $L M 6536 D \times \mathbf{L M} 13508 \mathbf{T}$ & $($ Deli $\times$ Angola Novo-Redondo) selfed $\times$ La Mé \\
\hline 6 & LM 22963 & $L M 5468 D \times \mathbf{L M} 13508 \mathbf{T}$ & (Deli $\times$ Angola Novo-Redondo) selfed $\times$ La Mé \\
\hline 7 & LM 23256 & $L M 6356 D \times \mathbf{L M} 13508 \mathbf{T}$ & (Deli $\times$ Angola Novo-Redondo) selfed $\times$ La Mé \\
\hline 8 & LM 23169 & $L M 5468 D \times \mathbf{L M} 13511 \mathbf{T}$ & $($ Deli $\times$ Angola Novo-Redondo) selfed $\times$ La Mé \\
\hline 9 & LM 22723 & $L M 5475 D \times \mathbf{L M} 13511 \mathbf{T}$ & $($ Deli $\times$ Angola Novo-Redondo) selfed $\times$ La Mé \\
\hline 10 & LM 22822 & $L M 5466 D \times \mathbf{L M} 13513 \mathbf{T}$ & (Deli $\times$ Angola Novo-Redondo) selfed $\times$ La Mé \\
\hline 11 & LM 22957 & LM $13513 \mathbf{T} \times L M 6356 D$ & $($ Deli $\times$ Angola Novo-Redondo) selfed $\times$ La Mé \\
\hline 12 & LM 23528 & $\underline{L M 11311 D} \times \mathbf{L M} 13515 \mathbf{T}$ & $($ Deli $\times$ Angola Novo-Redondo $)$ selfed $\times($ La Mé $\times$ Sibiti $)$ \\
\hline 13 & LM 23166 & $L M 6356 D \times \mathbf{L M ~} 13515 \mathbf{T}$ & $($ Deli $\times$ Angola Novo-Redondo) selfed $\times$ La Mé \\
\hline 14 & LM 22795 & $L M 5475 D \times \mathbf{L M} 13515$ T & (Deli $\times$ Angola Novo-Redondo) selfed $\times$ La Mé \\
\hline 15 & LM 22972 & $L M 3390 T \times \mathbf{L M} 13509 \mathbf{D}$ & $($ Deli $\times$ Angola Novo-Redondo) selfed $\times$ La Mé \\
\hline 16 & LM 22835 & LM $13516 \mathbf{D} \times L M 5005 T$ & (Deli $\times$ Angola Novo-Redondo) selfed $\times$ La Mé \\
\hline 17 & LM 22966 & $L M 5466 D \times \mathbf{L M} 13517 \mathbf{P}$ & $($ Deli $\times$ Angola Novo-Redondo) selfed $\times$ La Mé \\
\hline 18 & LM 23957 & $L M 6536 D \times \mathbf{L M} 13517 \mathbf{P}$ & $($ Deli $\times$ Angola Novo-Redondo) selfed $\times$ La Mé \\
\hline 19 & LM 22993 & LM 5468 D $\times$ LM 13519 P & (Deli $\times$ Angola Novo-Redondo) selfed $\times$ La Mé \\
\hline 20 & LM22794 & $L M 5475 D \times \mathbf{L M} 13519$ P & (Deli $\times$ Angola Novo-Redondo) selfed $\times$ La Mé \\
\hline 21 & LM 23731 & $\underline{L M 13524 D} \times \mathbf{L M} 13523 \mathbf{P}$ & $($ Deli $\times$ Angola Novo-Redondo) selfed × $($ La Mé $\times$ Sibiti $)$ \\
\hline 22 & LM 23982 & $\underline{L M 11311 D} \times \mathbf{L M} 13523 \mathbf{P}$ & $($ Deli $\times$ Angola Novo-Redondo $)$ selfed $\times($ La Mé $\times$ Sibiti $)$ \\
\hline 23 & LM 23306 & $L M 5475 D \times \mathbf{L M} 13523 \mathbf{P}$ & (Deli $\times$ Angola Novo-Redondo) selfed $\times$ La Mé \\
\hline 24 & LM 22480 & LM $13518 \mathbf{D} \times L M 5911 T$ & $($ Deli $\times$ Angola Novo-Redondo) selfed $\times$ La Mé \\
\hline 25 & LM 22454 & LM $13518 \mathrm{D} \times L M 5005 T$ & $($ Deli $\times$ Angola Novo-Redondo) selfed $\times$ La Mé \\
\hline
\end{tabular}

Note. In bold (LM 13508 T) group A genitor from (Deli $\times$ Angola Novo-Redondo) selfed; in bold and underlined (LM 2536 D) group A genitor from Deli origin; in italics (LM 2 T) group B genitor from La Mé origin; in italics and underlined $(\underline{L M 11311 D})$ Group B genitor from (La Mé $\times$ Sibiti) cross; *: (Group B $\times$ Group A) control combinations; **: (Deli $\times$ Angola Novo-Redondo) genitor selfed whose descendants were used in the La Mé $\times$ $($ Deli $\times$ Angola Novo-Redondo) selfed and $($ La Mé $\times$ Sibiti $) \times($ Deli $\times$ Angola Novo-Redondo) selfed inter-group combinations.

\subsection{Parameters Recorded}

\subsubsection{Bunch Number and Total Bunch Weight}

Bunch number (BN) and corresponding total weight (TBW) were recorded on per tree basis during each of the 3 harvesting rounds carried out per month from 2012 to 2015. The average bunch weight (ABW) was deducted from the total weight of bunches and the number of bunches using the following arithmetic formula:

$$
\mathrm{PMR}=\mathrm{PTR} / \mathrm{NR}
$$

Progeny's bunch yield (BY) was performed using the following formula:

$$
\mathrm{BY}=\mathrm{TBW} \times \mathrm{D} \times 0.95
$$

Where, BY is the bunch yield, TBW is annual mean individual total bunch weight, $\mathrm{D}$ is planting density $(\mathrm{D}=$ 143 in the progeny trial), 0.95 is a coefficient estimating that palms morphologically abnormal and palms weakened by diseases and/or pest attacks are equivalent to a loss of $5 \%$ of the trees per hectare planted.

\subsubsection{Bunch Characteristics}

Two bunches harvested, one in the rainy season and the other in the dry season, only from tenera palms of each progeny were analysed to determine the percentage of fruit to bunch $(\mathrm{F} / \mathrm{B})$, the percentage of mesocarp (or pulp) 
to fruit $(\mathrm{M} / \mathrm{F})$, and the oil to mesocarp ratio $(\mathrm{O} / \mathrm{M})$. Data collected helped in estimating the industrial oil extraction rate (OER) and oil yield (OY) using the following formulas:

$$
\begin{aligned}
\mathrm{OER}=\mathrm{F} / \mathrm{B} \times \mathrm{M} / \mathrm{F} \times \mathrm{O} / \mathrm{M} \times 0.855 \\
\mathrm{OY}=\mathrm{BY} \times \mathrm{OER}
\end{aligned}
$$

Where, 0.855 is a factor that takes into account various losses of oil during its extraction in the palm oil mill.

\subsubsection{Vertical Growth Rate (VGR)}

The palm height was measured at 6 years after planting at the axil of leaf 33 . Leaf 33 is located approximately at the level of the ripe bunches and very often bears a rotten male inflorescence. The height of the palm tree was then read at ground level (Jacquemard, 1980). The growth rate was determined by the following formula:

$$
\mathrm{VGR}=\mathrm{H} /(\mathrm{n}-3.75)
$$

Where, VGR is the vertical growth rate, $\mathrm{H}$ is the palm height, $\mathrm{n}$ is age of the palm in years, 3.75 (years) is the age at which the growth in height starts, since before this age the palm grows transversely to ensure that the root bulb is well embedded in the soil.

\subsubsection{Fusarium Index}

A sample of 160 seedlings per progeny aged 2 months was used for the test of tolerance to Fusarium wilt. A few roots were exposed and scraped to create lesions, rinsed with distilled water. Then, $20 \mathrm{ml}$ of inoculum of a cultivated strain of Fusarium oxysporum f. sp. elaeidis containing about $5 \times 10^{5}$ spores $/ \mathrm{ml}$ were poured onto the roots. After spore inoculation, the roots were covered with soil. Recording of symptoms and stunted seedlings began one month after inoculation. After 5 months, the pseudo-bulb of each seedling was sectioned to allow visualisation of tissues' browning, an internal symptom, which indicates the presence of the pathogenic fungus in the seedling. The Fusarium wilt status of each progeny tested was related to the average percentage of seedlings showing external and/or internal symptoms in the whole test. A progeny Fusarium Index (FI) was determined as follows:

$$
\mathrm{FI}=\frac{\text { Percentage of infected seedlings of the progeny }}{\text { Percentage of infected seedlings of all progenies }} \times 100
$$

The threshold for the estimation of progeny tolerance to Fusarium wilt was set at 100. Thus, progenies with FI $>$ 100 were considered susceptible to the disease and those with FI $<100$ were qualified tolerant.

\subsection{Statistical Analysis}

The Student's unpaired t-test was used to compare each of the (Deli $\times$ Angola Novo-Redondo) $\times$ La Mé, (Deli $\times$ Angola Novo-Redondo) selfed $\times($ La Mé $\times$ Sibiti), $($ La Mé $\times$ Deli) combinations to (Deli $\times$ Angola Novo-Redondo) selfed $\times$ La Mé for (i) bunch yield and its components, (ii) vertical growth rate, and (iii) bunch characteristics.

Analyses of variance were performed to determine the combining abilities of [(Deli $\times$ Angola Novo-Redondo) selfed] genotypes, Deli, La Mé, and (Sibiti $\times$ La Mé) testers. The following general linear model described by Salami and Agbowuro (2016) was used for bunch production and its components, vertical growth rate, and bunch characteristics:

$$
\mathrm{Y}_{\mathrm{ijk}}=\mu+\mathrm{m}_{\mathrm{i}}+\mathrm{f}_{\mathrm{j}}+\mathrm{mf}_{\mathrm{ij}}+\mathrm{e}_{\mathrm{ijk}}
$$

Where, $Y_{\mathrm{ijk}}$ is the value of the offspring of the cross between male sire $\mathrm{i}$ and female sire $\mathrm{j}$ in replicate $\mathrm{k}, \mu$ is the trial mean, $m_{i}$ is the effect of male parent $i, f_{j}$ is the effect of female parent $j, m_{i j}$ is the interaction between male $\mathrm{i}$ and female $\mathrm{j}, \mathrm{e}_{\mathrm{ijk}}$ is the within-plot residual.

Grouping of mean values of the progenies was performed using Duncan's Multiple Range Test (DMRT). Breeding values of [(Deli $\times$ Angola Novo-Redondo $)$ selfed] genitors were estimated as defined by Corley and Tinker (2003).

\section{Results and Discussion}

\subsection{Comparison of Different Combination Types}

Each of the combinations La Mé $\times($ Deli $\times$ Angola Novo-Redondo), (Deli $\times$ Angola Novo-Redondo $)$ selfed $\times($ La Mé $\times$ Sibiti), and (La Mé $\times$ Deli) was compared to (Deli $\times$ Angola Novo-Redondo) selfed $\times$ La Mé using Student test. TBW mean values varied from $156.4 \pm 49.35 \mathrm{~kg} \mathrm{palm}^{-1} \mathrm{yr}^{-1}$ for (La Mé $\times$ Deli) to168.1 $\pm 55.15 \mathrm{~kg} \mathrm{palm}^{-1} \mathrm{yr}^{-1}$ for (Deli $\times$ Angola Novo-Redondo) selfed $\times$ La Mé. Combinations involving (Deli $\times$ Angola Novo-Redondo) selfed have produced $15 \%$ more bunches than the controls (La Mé $\times$ Deli), on average. The Student test showed 
the superiority of (Deli $\times$ Angola Novo-Redondo) selfed-derived combinations for TBW and BN (Table 2). The high TBW observed was most probably due to their high BN. Darkwah et al (2020a) selected 7 dura accessions from Ghana for their high TBW contributed by high BN and ABW. Lubis et al. (1991) moved further and found that BN was a predominant factor in TBW and palm oil production. Recently, Isa et al. ((2009) also reported from their study of the variation in yield and yield components in Malaysian oil palm (Elaeis guineensis Jacq.) D $\times$ P planting materials under various planting density that the highest fresh fruit bunch (or TBW) obtained were attributed to high mean BN. The high ABW of (La Mé $\times$ Deli) and (Deli $\times$ Angola Novo-Redondo) derived-combinations did not compensate for the low BN. Furthermore, Isa et al. (2009) found positive correlation between TBW and BN $(r=0.69)$ and a negative correlation between $\mathrm{BN}$ and $\mathrm{ABW}(\mathrm{r}=-0.43)$ at a planting density of 148 palms ha $^{-1}$ which was the closest to 143 palms ha ${ }^{-1}$ of the current study. Globally, the vertical growth rate of (Deli $\times$ Angola Novo-Redondo) selfed-derived combinations was comparable to those of the controls (La Mé $\times$ Deli) and (Deli $\times$ Angola Novo-Redondo) $\times$ La Mé combination. Growth rates, independently of the combinations type, were less than $50 \mathrm{~cm} \mathrm{yr}^{-1}$ considered as slow growth rate for current planting materials.

Table 2. Comparison of (Deli $\times$ Angola Novo-Redondo) selfed $\times$ La Mé combinations to each of the (Deli $\times$ Angola Novo-Redondo) self $\times($ La Mé $\times$ Sibiti), La Mé $\times($ Deli $\times$ Angola Novo-Redondo), and (La Mé $\times$ Deli) combinations for bunch production and its components and vertical growth rate

\begin{tabular}{|c|c|c|c|c|c|c|c|c|c|c|}
\hline \multirow{2}{*}{ Combinaisons } & \multirow{2}{*}{ df } & \multicolumn{2}{|c|}{ TBW $\left(\mathrm{kg} \mathrm{yr}^{-1}\right)$} & \multicolumn{2}{|c|}{$\mathrm{BN}$} & \multicolumn{2}{|c|}{$\mathrm{ABW}(\mathrm{kg})$} & \multicolumn{3}{|c|}{$\operatorname{VGR}\left(\mathrm{cm} \mathrm{yr}^{-1}\right)$} \\
\hline & & Mean & $t$ & Mean & $t$ & Mean & $t$ & df & Mean & $t$ \\
\hline$($ Deli $\times$ Angola Novo-Redondo) selfed $\times$ La Mé & & $168.1 \pm 55.15$ & & $10.61 \pm 4.11$ & & $16.62 \pm$ & & & $48.5 \pm 6$ & \\
\hline$($ Deli $\times$ Angola Novo-Redondo $)$ selfed $\times($ La Mé $\times$ Sibiti $)$ & 7972 & $163.3 \pm 60.88$ & $2.69^{* *}$ & $9.97 \pm 4.00$ & $4.86^{* * *}$ & $17.10 \pm$ & $53.75^{* * *}$ & 199 & $47.4 \pm 6$ & $2.56^{* *}$ \\
\hline La Mé $\times($ Deli $\times$ Angola Novo-Redondo $)$ & 7213 & $156.3 \pm 59.91$ & $4.05^{* * *}$ & $9.02 \pm 3.67$ & $7.31^{* * *}$ & $17.92 \pm$ & $66.39^{* * *}$ & 180 & $47.7 \pm 6$ & $1.08^{\mathrm{ns}}$ \\
\hline La Mé × Deli & 7981 & $156.4 \pm 49.35$ & $6.76^{* * *}$ & $8.97 \pm 3.25$ & $12.80^{* * *}$ & $18.06 \pm$ & $311.78^{* * *}$ & 199 & $48.3 \pm 6$ & $0.57^{\mathrm{ns}}$ \\
\hline
\end{tabular}

Note. Df: degree of freedom; TBW: total bunch weight; BN: bunch number; ABW: average bunch weight; VGR: vertical growth rate; $t$ : value of Student statistic; **: value significant at $1 \% ; * * *$ : value significant at $1 \%$; ${ }^{\text {ns }}$ : value not significant.

(Deli $\times$ Angola Novo-Redondo) selfed-derived combinations were close to the original combination La Mé $\times$ (Deli $\times$ Angola Novo-Redondo) and to the controls (Deli $\times$ La Mé) for F/B and O/M. They differ for M/F that led to a difference between combinations for oil extraction rate (Table 3). Bakoumé et al. (2010) found that self-pollination of dura considerably affects $\mathrm{M} / \mathrm{F}, \mathrm{O} / \mathrm{M}$, and subsequently OER. However, relatively high oil yield (OY) was obtained from (Deli $\times$ Angola Novo-Redondo) selfed-derived combinations with high TBW and $\mathrm{BN}$ given the positive correlations between $\mathrm{BN}$ and $\mathrm{OY}$ as well as between TBW and $\mathrm{OY}(\mathrm{r}=0.63$ and $\mathrm{r}=0.91$, respectively) (Isa et al., 2009).

Table 3. Comparison of (Deli $\times$ Angola Novo-Redondo) selfed $\times$ La Mé combinations to each of the (Deli $\times$ Angola Novo-Redondo) self $\times($ La Mé $\times$ Sibiti), La Mé $\times($ Deli $\times$ Angola Novo-Redondo), and (La Mé $\times$ Deli) combinations for bunch characteristics

\begin{tabular}{|c|c|c|c|c|c|c|c|c|c|}
\hline \multirow{2}{*}{ Combinaisons } & \multirow{2}{*}{$\mathrm{df}$} & \multicolumn{2}{|c|}{$\mathrm{F} / \mathrm{B}(\%)$} & \multicolumn{2}{|c|}{$\mathrm{M} / \mathrm{F}(\%)$} & \multicolumn{2}{|c|}{$\mathrm{O} / \mathrm{M}(\%)$} & \multicolumn{2}{|c|}{ OER $(\%)$} \\
\hline & & Mean & $t$ & Mean & $t$ & Mean & $t$ & Mean & $t$ \\
\hline$($ Deli $\times$ Angola Novo-Redondo) selfed $\times$ La Mé & & $62.36 \pm 6.92$ & & $74.26 \pm 5.70$ & & $59.28 \pm 8.13$ & & $27.27 \pm 5.37$ & \\
\hline$($ Deli $\times$ Angola Novo-Redondo $)$ selfed $\times($ La Mé $\times$ Sibiti $)$ & 804 & $64.12 \pm 7.15$ & $2.46^{* *}$ & $71.12 \pm 4.53$ & $5.49^{* * *}$ & $61.96 \pm 7.03$ & $3.27^{* * *}$ & $28.41 \pm 4.84$ & $2.10^{*}$ \\
\hline La Mé × (Deli × Angola Novo-Redondo $)$ & 726 & $65.83 \pm 5.78$ & $2.74^{* *}$ & $76.63 \pm 4.99$ & $2.28^{*}$ & $60.48 \pm 7.03$ & $0.81^{\mathrm{ns}}$ & $31.56 \pm 5.46$ & $4.29^{* * *}$ \\
\hline La Mé × Deli & 781 & $62.09 \pm 5.31$ & $0.35^{\text {ns }}$ & $77.85 \pm 5.40$ & $5.55^{* * *}$ & $59.15 \pm 9.03$ & $0.13^{\mathrm{ns}}$ & $29.63 \pm 6.75$ & $3.74^{* * *}$ \\
\hline
\end{tabular}

Note. df: degree of freedom; F/B: fruit to bunch ratio; M/F: mesocarp to fruit ratio; O/M: oil to mesocarp ratio; OER: oil extraction rate; $t$ : value of Student statistic; *: value significant at $5 \%$; **: value significant at $1 \%$; ***: value significant at $1 \%$; ${ }^{\text {ns }}$ : value not significant.

\subsection{Progenies Performances for Bunch Production and Its Components and Vertical Growth Rate}

The total bunch weight of [(Deli $\times$ Angola Novo-Redondo) selfed $\times$ La Mé] progenies varied from $164.15 \mathrm{~kg}$ palm $\mathrm{yr}^{-1}\left(22.16 \mathrm{t} \mathrm{ha}^{-1}\right)$ to $177.15 \mathrm{~kg} \mathrm{palm}^{-1} \mathrm{yr}^{-1}\left(23.92 \mathrm{tha}^{-1}\right)$. The mean TBW $\left(168.43 \mathrm{~kg} \mathrm{palm}^{-1} \mathrm{yr}^{-1}\right)$ was by $4 \%$ 
greater than the mean TBW of [(Deli $\times$ Angola Novo-Redondo $)$ selfed $\times($ Sibiti $\times$ La Mé $)]$ progenies and $8 \%$ higher than each of the $($ Deli $\times$ La Mé) and [La Mé $\times($ Deli $\times$ Angola Novo-Redondo)] progenies' means (155.72 $\mathrm{kg} \mathrm{palm}^{-1} \mathrm{yr}^{-1}$ and $156.07 \mathrm{~kg} \mathrm{palm}^{-1} \mathrm{yr}^{-1}$, respectively). The ANOVA revealed differences between male parents as well as between female parents including (Deli $\times$ Angola Novo-Redondo) selfed genitors for bunch production and its components and vertical growth rate as well (Table 4). Furthermore, very significant male parent $\times$ female parent interaction was detected with the exception of vertical growth rate. The ANOVA also revealed differences among male parents and among female parents for bunch characteristics except for mesocarp to fruit ratio (Table 5). However, the male parent $\times$ female parent interaction was not significant for all the bunch characteristics. The different genetic backgrounds of the genitors crossed led to the difference between male parents and between female parents. La Mé origin, Sibiti $\times$ La Mé combination were most probably genetically dissimilar. Selfing of (Deli $\times$ Angola Novo-Redondo) hydrid genitor (LM 5448 T) had generated different allele combinations during the formation of the $\mathrm{F}_{2}$ oil palm populations used in the (Deli $\times$ Angola Novo-Redondo) selfed $\times$ La Mé and (Deli $\times$ Angola Novo-Redondo) selfed $\times($ La Mé $\times$ Sibiti) crosses.

Table 4. Analysis of variance of total bunch weight and its production components and vertical growth rate

\begin{tabular}{|c|c|c|c|c|c|c|c|c|c|c|}
\hline \multirow{2}{*}{ Source of variation } & \multirow{2}{*}{$\mathrm{df}$} & \multicolumn{2}{|c|}{ TBW } & \multicolumn{2}{|c|}{$\mathrm{BN}$} & \multicolumn{2}{|c|}{$\mathrm{ABW}$} & \multicolumn{3}{|c|}{ Vertical Growth Rate } \\
\hline & & MS & $\mathrm{F}$ & MS & $\mathrm{F}$ & MS & $\mathrm{F}$ & $\mathrm{df}$ & MS & $\mathrm{F}$ \\
\hline Repetition & 5 & 58441.24 & $19.59^{* * *}$ & 113.22 & $7.92^{* * *}$ & 97.10 & $7.55^{* * *}$ & 5 & 10925.94 & $12.84^{* * *}$ \\
\hline Parent male & 13 & 19993.95 & $6.70^{* * *}$ & 1104.50 & $77.27^{* * *}$ & 1458.62 & $113.36^{* * *}$ & 12 & 12299.36 & $14.46^{* * *}$ \\
\hline Parent female & 15 & 15453.52 & $5.18^{* * *}$ & 232.83 & $16.29^{* * *}$ & 293.70 & $22.83^{* * *}$ & 14 & 9475.27 & $11.14^{* * *}$ \\
\hline Male $\times$ Female & 195 & 13431.33 & $4.50^{* *}$ & 153.11 & $10.71^{* * *}$ & 221.84 & $17.24^{* * *}$ & 168 & 1618.59 & $1.90^{\mathrm{ns}}$ \\
\hline Residual error & 9351 & 2982.95 & & 14.29 & & 12.87 & & 2227 & 850.65 & \\
\hline
\end{tabular}

Note. df: degree of freedom; TBW: total bunch weight; BN: bunch number; ABW: average bunch weight; MS: mean square; F: Fisher value calculated; *: value significant at $5 \%$; **: value significant at $1 \%$; ***: value significant at $1 \%$; ${ }^{\text {ns: }}$ : value not significant.

Table 5. Analysis of variance of bunch characteristics

\begin{tabular}{|c|c|c|c|c|c|c|c|c|c|c|}
\hline \multirow{2}{*}{ Source of variation } & \multirow{2}{*}{$\mathrm{df}$} & \multicolumn{2}{|c|}{$\mathrm{F} / \mathrm{B}$} & \multicolumn{2}{|c|}{$\mathrm{M} / \mathrm{F}$} & \multicolumn{2}{|c|}{$\mathrm{O} / \mathrm{M}$} & \multicolumn{3}{|c|}{ OER } \\
\hline & & MS & $\mathrm{F}$ & MS & $\mathrm{F}$ & MS & $\mathrm{F}$ & df & MS & $\mathrm{F}$ \\
\hline Repetition & 5 & 86.74 & $2.19^{\mathrm{ns}}$ & 52.22 & $2.27^{*}$ & 387.79 & $0.86^{\mathrm{ns}}$ & 5 & 73.94 & $2.76^{*}$ \\
\hline Male parent & 12 & 369.43 & $9.34^{* * *}$ & 710.79 & $30.96^{* * *}$ & 413.50 & $0.91^{\mathrm{ns}}$ & 12 & 218.41 & $8.15^{* * *}$ \\
\hline Female parent & 13 & 249.29 & $6.30^{* * *}$ & 113.60 & $4.95^{* * *}$ & 437.38 & $0.96^{\mathrm{ns}}$ & 14 & 131.47 & $4.90^{* * *}$ \\
\hline Male $\times$ Female & 156 & 68.24 & $1.73^{\mathrm{ns}}$ & 27.54 & $1.20^{\mathrm{ns}}$ & 311.24 & $0.69^{\mathrm{ns}}$ & 168 & 48.83 & $1.82^{\mathrm{ns}}$ \\
\hline Residual error & 775 & 39.54 & & 22.96 & & 453.36 & & 2227 & 26.81 & \\
\hline
\end{tabular}

Note. df: degree of freedom; F/B: fruit to bunch; M/F: mesocarp to fruit; O/M: oil to mesocarp; OER: oil extraction rate; MS: mean square; F: Fisher value calculated; *: value significant at $5 \%$; **: value significant at $1 \% ; * *$ : value significant at $1 \%$; ${ }^{\text {ns }}$ : value not significant.

The DMRT presented groups of means of TBW, BN, ABW and vertical growth rate overlapping each other. The results indicated that (Deli $\times$ Angola Novo-Redondo) selfed-derived progenies were comparable to the controls, of the current commercial planting materials (Table 6). Coefficients of variation of TBW, oil yield and vertical growth rate were low. They varied from $3 \%$ for TBW to $8 \%$ for oil yield further supporting progeny homogeneity. The 21 (Deli $\times$ Angola Novo-Redondo) selfed-derived progenies were comparable to the 3 (La Mé $\times$ Deli) control progenies for oil yield $\left(6.22 \mathrm{t} \mathrm{ha}^{-1}\right.$ versus $\left.6.17 \mathrm{t} \mathrm{ha}^{-1}\right)$, and comparable vertical growth rate with the current commercial material $\left(48.45 \mathrm{~cm} \mathrm{yr}^{-1}\right.$ versus $\left.48.41 \mathrm{~cm} \mathrm{yr}^{-1}\right)$. However, they recorded $8 \%$ more TBW than the 3 (La Mé $\times$ Deli) control progenies $\left(167.50 \mathrm{~kg} \mathrm{palm}^{-1} \mathrm{yr}^{-1}\right.$ versus $\left.155.72 \mathrm{~kg} \mathrm{palm}^{-1} \mathrm{yr}^{-1}\right)$. Similarity for oil yields derived from the low M/F of (Deli $\times$ Angola Novo-Redondo) selfed-derived progenies despite their high TBW. The low M/F probably resulted from the inbreeding depression usually due to self-pollination in oil palm. Bakoumé et al. (2010) reported that inbreeding depression reduced bunch characteristics including $\mathrm{M} / \mathrm{F}$ of (DA 3 D $\times$ DA 5 D) selfed-derived progenies. Besides, low M/F implied low OER. 
Table 6. Comparison of mean values of fresh bunch production components at maturity and vertical growth rate

\begin{tabular}{|c|c|c|c|c|c|c|c|c|c|c|c|}
\hline \multicolumn{9}{|c|}{ Bunch production at maturity } & \multirow{2}{*}{\multicolumn{3}{|c|}{ Vertical Growth Rate }} \\
\hline \multicolumn{3}{|c|}{ TBW } & \multicolumn{3}{|c|}{$\mathrm{BN}$} & \multicolumn{3}{|c|}{$\mathrm{ABW}(\mathrm{kg})$} & & & \\
\hline Progeny No. & $\begin{array}{l}\text { Mean } \\
\left(\mathrm{kg} \mathrm{palm}^{-1} \mathrm{yr}^{-1}\right)\end{array}$ & Grouping & Progeny No. & Mean & Grouping & Progeny No. & $\begin{array}{l}\text { Mean } \\
\left(\mathrm{kg} \mathrm{palm}^{-1}\right)\end{array}$ & Grouping & Progeny No. & $\begin{array}{l}\text { Mean } \\
\left(\mathrm{cm} \mathrm{yr}^{-1}\right)\end{array}$ & Grouping \\
\hline 16 & 177.15 & $\mathrm{a}$ & 25 & 13.89 & & 12 & 19.30 & $\mathrm{a}$ & 14 & 53.16 & $\mathrm{a}$ \\
\hline 10 & 174.95 & $a b$ & 24 & 13.45 & $\mathrm{a}$ & 10 & 18.82 & $a b$ & 23 & 52.16 & $\mathrm{ab}$ \\
\hline 22 & 174.51 & $a b$ & 19 & 11.29 & $\mathrm{~b}$ & 4 & 18.78 & $a b$ & 9 & 50.88 & $\mathrm{abc}$ \\
\hline 9 & 173.99 & $a b$ & 9 & 11.17 & $\mathrm{bc}$ & 2 & 18.58 & $a b c$ & 1 & 50.12 & bcd \\
\hline 23 & 173.43 & $a b$ & 21 & 11.05 & bcd & 13 & 18.18 & $\mathrm{bc}$ & 13 & 50.04 & bcd \\
\hline 19 & 172.23 & $a b$ & 20 & 10.97 & bcde & 3 & 18.02 & bcd & 8 & 49.80 & bcd \\
\hline 20 & 171.11 & $a b$ & 23 & 10.93 & bcde & 11 & 17.78 & cde & 10 & 49.68 & bcde \\
\hline 5 & 169.03 & $a b c$ & 8 & 10.85 & bcde & 16 & 17.78 & cde & 20 & 49.48 & bcdef \\
\hline 6 & 168.31 & $a b c$ & 22 & 10.85 & bcde & 5 & 17.66 & cdef & 7 & 48.84 & cdefg \\
\hline 8 & 168.31 & $a b c$ & 15 & 10.33 & bcdef & 17 & 17.18 & defg & 11 & 48.72 & cdefg \\
\hline 7 & 167.55 & abcd & 14 & 10.29 & bcdefg & 7 & 17.14 & defg & 12 & 48.60 & cdefg \\
\hline 14 & 165.87 & abcd & 6 & 10.25 & bcdefg & 18 & 16.98 & efgh & 15 & 48.48 & cdefg \\
\hline 24 & 165.35 & abcd & 16 & 10.17 & cdefgh & 6 & 16.74 & fgh & 3 & 48.04 & defg \\
\hline 15 & 164.83 & abcd & 1 & 10.13 & cdefgh & 1 & 16.58 & $\mathrm{gh}$ & 24 & 47.84 & defg \\
\hline 18 & 164.63 & abcd & 7 & 10.09 & cdefgh & 14 & 16.58 & gh & 2 & 47.56 & defg \\
\hline 25 & 164.15 & abcd & 18 & 9.97 & defgh & 9 & 16.54 & gh & 4 & 47.56 & defg \\
\hline 11 & 163.71 & abcd & 5 & 9.89 & efgh & 22 & 16.50 & gh & 16 & 47.48 & defg \\
\hline 13 & 163.59 & abcd & 17 & 9.57 & fghi & 23 & 16.50 & gh & 22 & 47.32 & defg \\
\hline 17 & 163.55 & abcd & 10 & 9.41 & fghi & 15 & 16.38 & gh & 5 & 47.28 & defg \\
\hline 1 & 162.95 & bcd & 11 & 9.41 & fghi & 8 & 16.14 & ghi & 17 & 46.92 & efg \\
\hline 21 & 162.51 & bcd & 13 & 9.21 & ghij & 19 & 16.14 & ghi & 21 & 46.68 & fgh \\
\hline 3 & 156.07 & cde & 3 & 9.13 & hij & 20 & 16.06 & hi & 6 & 46.64 & fgh \\
\hline 2 & 154.19 & de & 2 & 8.61 & ijk & 21 & 15.34 & $\mathrm{i}$ & 18 & 46.36 & $\mathrm{gh}$ \\
\hline 4 & 150.03 & $\mathrm{e}$ & 4 & 8.37 & $\mathrm{jk}$ & 24 & 13.26 & $\mathrm{j}$ & 25 & 44.20 & $\mathrm{~h}$ \\
\hline 12 & 148.75 & $\mathrm{e}$ & 12 & 7.97 & $\mathrm{k}$ & 25 & 12.54 & $\mathrm{j}$ & 19 & 44.16 & $\mathrm{~h}$ \\
\hline
\end{tabular}

Note. TBW: total bunch weight; BN: bunch number; ABW: average bunch weight; Progeny with the same letter are not significantly different.

Fusarium indices $(\mathrm{FI})$ of all the (Deli $\times$ Angola Novo-Redondo) selfed-derived progenies were relatively low (41-84) indicating that they were tolerant (or resistant) to Fusarium wilt. In fact, progenies with FI $<100$ are qualified tolerant to the disease. FI of (La Mé $\times$ Deli) control progenies were equal to 96 or 97 (Table not presented). Genitors descendants from (Deli $\times$ Angola Novo-Redondo) selfed that is LM $5448 \mathrm{~T}$ selfed might have predominantly contributed to the tolerance to Fusarium wilt expressed by their hybrid progenies. In fact, (Deli $\times$ Angola Novo-Redondo)'s LM 5448 T was selected in a recent study for its tolerance to Fusarium wilt (FI $=82$ ) in addition to its high bunch and oil yields (Adon et al., 2021).

The main aims of oil palm breeding in Africa including Côte d'Ivoire are to maximize palm oil (and kernel) yield, to reduce vertical growth to extend the plant's economic life, and to explore new sources of tolerance to Fusarium wilt (Bakoumé et al., 2016). In a recent study aiming to select elites genotypes within natural oil palm accessions collected in Ghana, Darkwah et al. (2020b) confirmed the high heritability of TBW $\left(\mathrm{h}^{2}=0.52\right)$, a feature that indicated the possibility to get it (heritability) expressed in subsequent generations. Three progenies (LM 22723, LM 22835, LM 23169) out of the 8 that ranked first for oil yield were derived from crosses involving (Deli $\times$ Angola Novo-Redondo) selfed. They possessed relatively high TBW and BN $((11 \%$ and $22 \%$ more than the controls, respectively) (Table 7). The trend was observed for oil yield. According to Isa et al. (2009), oil yield is mostly dependent on TBW and BN. Darkwah et al. (2020b), a Ghanaian Oil Palm Research Institute (OPRI) team, supported the interest of breeding programs in dura parents of relatively high number of bunches for further improvement of this character in the tenera. The team carried out an evaluation of the genetic variability of TBW and $\mathrm{BN}$ among other agronomic and morphological traits of natural dura accessions for the selection of elite ones to introduce in the advanced dura stocks. The 3 progenies' vertical growth rate values represented $2 \%$ and $8 \%$ rise over the trial mean and (La Mé $\times$ Deli) control progenies' mean, respectively. Darkwah et al. (2020b) selected 5 genotypes whose mean VGR represented 7\% increase over the controls' mean. Furthermore, the 3 progenies selected were tolerant to Fusarium wilt $(\mathrm{FI}=32-79)$. Therefore, the 3 progenies viz LM 22723, LM 22835, and LM 23169 should be added to the commercial seed production programme. Vertical 
growth rate constituted a minor constraint because shorter descendants of (Deli $\times$ Angola Novo-Redondo) selfed would be selected for use in the seed production.

Table 7. Bunch production, bunch characteristics and vertical growth rate of the best (Deli $\times$ Angola Novo-Redondo) selfed-derived progenies

\begin{tabular}{|c|c|c|c|c|c|c|c|c|c|c|c|}
\hline Progeny & Cross type & Oil $\left(\mathrm{t} \mathrm{ha}^{-1}\right)$ & ) TBW ( $\left.\mathrm{kg} \mathrm{palm}^{-1} \mathrm{yr}^{-1}\right)$ & $\mathrm{BN}$ & $\mathrm{ABW}(\mathrm{kg})$ & $\mathrm{F} / \mathrm{B}(\%)$ & $\mathrm{M} / \mathrm{F}(\%)$ & $\mathrm{O} / \mathrm{M}(\%)$ & OER $(\%)$ & $\operatorname{VGR}\left(\mathrm{cm} \mathrm{yr}^{-1}\right)$ & FI \\
\hline LM 22835 & LM 13516 D $\times$ LM $5005 \mathrm{~T}$ & 7.17 & 177.15 & 10.16 & 17.78 & 61 & 79 & 60 & 30 & 47.48 & 79 \\
\hline LM 22723 & LM 5475 D $\times$ LM 13511 T & 6.58 & 173.99 & 11.17 & 16.54 & 64 & 71 & 58 & 28 & 50.88 & 56 \\
\hline LM 23169 & LM $5468 \mathrm{D} \times$ LM $13511 \mathrm{~T}$ & 6.36 & 168.31 & 10.85 & 17.78 & 64 & 72 & 60 & 28 & 49.80 & 32 \\
\hline \multicolumn{2}{|l|}{ Mean } & 6.70 & 173.15 & 10.73 & 17.37 & 63 & 74 & 59 & 29 & 49.80 & 56 \\
\hline \multicolumn{2}{|l|}{ Trial mean } & 6.23 & 165.25 & 10.29 & 16.86 & 63 & 74 & 61 & 28 & 48.32 & 56 \\
\hline \multicolumn{2}{|c|}{ (La Mé $\times$ Deli) controls' mean } & 6.17 & 155.72 & 8.80 & 14.91 & 62 & 75 & 59 & 29 & 45.83 & 97 \\
\hline
\end{tabular}

Note. Oil: oil yield; TBW: total bunch weight; BN: bunch number; ABW: average bunch weight; F/B: fruit to bunch; M/F: mesocarp to fruit; O/M: oil to mesocarp; OER: oil extraction rate; VGR; vertical growth rate; FI: Fusarium index.

\subsection{Breeding Values of (Deli $\times$ Angola Novo-Redondo) Selfed Genitors of Progenies Intended to Seed Production}

The breeding value of a genitor is the average value of all the progenies from the genitor concerned (Corley $\&$ Tinker, 2003). Two (2) genitors from (Deli $\times$ Angola Novo-Redondo) selfed which were parents of the 3 progenies selected including 1 dura (LM 13516 D) and 1 tenera (LM $13511 \mathrm{~T})$. The 2 genitors' breeding values for bunch production, bunch characteristics, oil yield, and vertical growth rate were presented in Table 8 . Their mean oil yield was $6.74 \mathrm{t} \mathrm{ha}^{-1}$ contributed by $23.22 \mathrm{t} \mathrm{ha}^{-1}$ of bunches, $63 \%$ fruit to mesocarp, and $29 \% \mathrm{O} / \mathrm{M}$. Breeding values of the two genitors were considered satisfactory for the present study. Corley and Tinker (2003) also defined a breeding value of a parent as a difference between the average value of all the progenies from the genitor concerned and the overall mean for the trial. The breeding value calculated using the preceding expression were $5.75 \mathrm{~kg}$ palm $^{-1} \mathrm{yr}^{-1}$ and $7.75 \mathrm{~kg} \mathrm{palm}^{-1} \mathrm{yr}^{-1}$ for LM $13511 \mathrm{~T}$ and LM $13516 \mathrm{D}$, respectively for TBW. The rest of the breeding values of the 2 genitors, all parameters put together were comprised between $-2 \%$ for $\mathrm{F} / \mathrm{B}$ and $1.68 \mathrm{~cm} \mathrm{yr}^{-1}$ for VGR, independently of the genitor (Table not shown) indicating that the individual performances were too close to the trial means and could be well considered relatively high. In fact, the trial performed significantly better for bunch production, oil yield than the (La Mé $\times$ Deli) control progenies which were representatives of the best planting materials of the second selection cycle. The breeding values obtained would be used to predict the performances of progenies derived from crosses where they would be involved. According to Corley and Tinker (2003), the expected performances of progenies to be reproduced will be simply the mean values of the two parents. In addition, Sparnaaij \& van der Vossen (1980) recommended that in breeding for oil yield in oil palm, breeding values should be exploited by crossing parents with contrasting yield components. Therefore, it would be imperative to determine the breeding values of the 2 genitors' partners prior to the preparation of the seed production crossing chart.

Table 8 . Genetic values of genitors for production of (Deli $\times$ Angola Novo-Redondo) selfed $\times$ La Mé commercial seeds

\begin{tabular}{llllllllll}
\hline Genitor & Oil $\left(\mathrm{t} \mathrm{ha}^{-1}\right)$ & TBW $\left(\mathrm{kg} \mathrm{palm}^{-1} \mathrm{yr}^{-1}\right)$ & $\mathrm{BN}$ & $\mathrm{ABW}(\mathrm{kg})$ & $\mathrm{F} / \mathrm{B}(\%)$ & $\mathrm{M} / \mathrm{F}(\%)$ & $\mathrm{O} / \mathrm{M}(\%)$ & OER $(\%)$ & VGR $\left(\mathrm{cm} \mathrm{yr}^{-1}\right)$ \\
\hline LM 13516 D & 7.01 & 173 & 10 & 18 & 61 & 79 & 60 & 30 & 48 \\
LM 13511 T & 6.46 & 171 & 11 & 16 & 64 & 72 & 59 & 28 & 50 \\
Mean & 6.74 & 172 & 11 & 17 & 63 & 76 & 60 & 29 & 49 \\
\hline
\end{tabular}

Note. Oil: oil yield; TBW: total bunch weight; BN: bunch number; ABW: average bunch weight; F/B: fruit to bunch; M/F: mesocarp to fruit; O/M: oil to mesocarp; OER: oil extraction rate; VGR: vertical growth rate.

\section{Conclusion}

The Mé Oil Palm Research station has successfully introduced additional blood (Angola Novo-Redondo blood) into to the Deli origin, the unique of group A of RRS until now. It has revealed the good performances of (Deli $\times$ Angola Novo-Redondo) selfed $\times$ La Mé progenies for oil yield due to their high TBW and BN over (La Mé $\times$ Deli) control progenies; best planting materials of the second cycle of RRS carried out in Côte d'Ivoire. The 
study has provided oil palm growers with 3 (Deli $\times$ Angola Novo-Redondo) selfed $\times$ La Mé commercial progenies with additional gene for tolerance to Fusarium wilt and high bunch production and oil yield through the introduction of the Angola Novo-Redondo germplasm. The new progenies are relatively superior to the current planting materials derived from the second selection cycle. Based on the breeding values obtained from the progenies' parents, seed production should put emphasis on crossing individuals with contrasting bunch and oil parameters for improved yields. Furthermore, continuous production of LM 13516 D, LM 15311 T descendants for commercial seeds production should be taken a second look to prevent inbreeding depression in intra-group hybrids.

\section{Acknowledgements}

Authors would like to sincerely thank workers from La Mé Oil Palm Research Station for the trial upkeep, data recording, and bunch analyses performed. They are grateful to Dr. Michel Ndoumbé Nkeng for his constructive comments on the statistical analyses.

\section{References}

Adon, B. (1995). Evaluation of oil palm (Elaeis guineensis Jacq.) introductions: Use in the selection scheme (Unpublished Doctoral Thesis, University of Cocody-Abidjan, Côte d'Ivoire).

Adon, B., Konan, J. N., Cochard, C., Flori, A., Diabaté, S., Bakoumé, C., \& Sokouri, D. P. (2021). Agronomical Performances of Angolan Natural Oil Palm Accessions and Interests for Oil Palm Selection in Côte d'Ivoire. Journal of Agricultural Science, 13(11), 64-73. https://doi.org/10.5539/jas.v13n11p64

Armitage, P., \& Berry, G. (1994). Statistical Methods in Medical Research. Blackwell Science, Oxford.

Bakoumé, C. (2016). Genetic diversity, erosion and conservation in oil palm. In M. R. Ahaja \& S. Mohan Jain (Eds.), Genetic diversity and erosion in plants-Case studies (pp. 1-31). Springer International Publishing, AL, Zurich. https://doi.org/10.1007/978-3-319-25954-3_1

Bakoumé, C. (2018). Sustainability of African oil palm agriculture in a changing climatic environment. Food Science and Nutrition Technology, 3(5), 000164. https://doi.org/10.23880/fsnt-16000164

Bakoumé, C., Madi, G., \& Tengoua, F. F. (2010). Experimental modification of reciprocal recurrent selection in oil palm breeding in Cameroun. Euphytica, 171, 235-240. https://doi.org/10.1007/s10681-009-0034-1

Bakoumé, C., Ngando Ebongué, G., Ajambang, W., Ataga, C. D., Okoye, M. N., Enaberue, L. O., ... Etta, C. E. (2016). Oil palm breeding and seed production in Africa. Paper presented at the International Seminar on Oil Palm Breeding and Seed Production and Field Visits, Kisaran, Indonesia.

Chaudhary, R. C. (1984). Introduction to plant breeding. Mohan Primlani for Oxford \& IBH Publishing, New Dehli.

Cochard, B., Durand-Gasselin, T., \& Adon, B. (2000). Oil palm genetic resources in the Côte d'Ivoire. Composition, assessment and use. In N. Rajanaidu \& D. Ariffin (Eds.), Proceedings of the International Symposium on Oil Palm Genetic Resources and Evaluation (pp. B1-B20). Malaysian Palm Oil Board, Kuala Lumpur.

Corley, R. H. V., \& Tinker, P. H. (2003). The oil palm (4th ed.). Blackwell Science Publishing, Oxford. https://doi.org/10.1002/9780470750971

Coulibaly, F. (2001). Etude technique et économique d'une plantation industrielle de palmier à huile. Institut Privé d'Agriculture Tropicale, Abidjan.

Darkwah, D. O., Essie, B., Amoatey, H., Enoch, S., Bakoumé, C., \& Agyei-Dwarko, D. (2020b). Genetic diversity and selection within natural dura oil palm accessions collected in Ghana for oil palm productivity improvement. Biodiversitas, 21(8), 3534-3538. https://doi.org/10.13057/biodid/d210815

Darkwah, O. D., Agyei-Dwarko, D., Sackitey Ossom, J., Osei Adu, S., Banafo, S., \& Bakoumé, C. (2020a). Germination of oil palm (Elaeis guineensis Jacq.) seeds-A function of heat treatment and progeny. Plant Cell Biotechnology and Molecular Biology, 22(39\&40), 59-66.

Friends of the Earth. (2018). Palm oil in the North American consumer market. Land, Forest \& Finance, Issue Brief. Retrieved August 5, 2021, from http://www.issue_brief_2_-_palm_oil_in_the_north_american_ consumer_market.pdf

Gascon, J. P., Le Guen, V., Nouy, B., Asmady, H., \& Kamga, F. (1988). Résultats d'essais de second cycle de sélection récurrente réciproque chez le palmier à huile Elaeis guineensis Jacq. Oléagineux, 43(1), 1-7. 
Hartley, C. W. S. (1988). The Oil Palm (Elaeis guineensis Jacq.). Scientific and Technical Publication, Longman, New York.

Isa, Z. A., Kushairi, A., Rafii, M. Y., Saleh, G., \& Rajanaidu, N. (2009). Variation in FFB and yield components in Malaysian oil palm (Elaeis guineensis Jacq.) $\mathrm{D} \times \mathrm{P}$ planting materials under various planting densities and their correlations with frond production, rachis length and height. Proceedings of Agriculture, Biotechnology \& Sustainability Conference on Palm Oil- Balancing Ecologics with Economics (pp. 700-732). Malaysian Palm Oil Board, Kuala, Lumpur.

Jacquemard, J. C. (1980). Méthode d'observation de la croissance en hauteur du palmier à huile. Oléagineux, 35(10), 439-442.

Kwanchai, A. G., \& Arturo, A. G. (1984). Statistical procedures for agricultural research. A Wiley-Interscience Publication, John Wiley \& Sons Inc, New York.

Salami, A. E., \& Agbowuro, G. O. (2016). Gene action and heritability estimates of grain yield and disease incidence traits of low-N maize (Zea mays L.) in inbred lines. Agriculture and Biology Journal of North America, 7(2), 50-54.

Sparnaaij, L. D., \& van der Vossen, H. A. M. (1980). Development in oil palm breeding: a reappraisal of present and future breeding procedures in light of the results from the Nigerian Institute for Oil Palm Research breeding programme. Oil Palm News, 24, 4-11.

\section{Abbreviations}

DA 10 D: $10^{\text {th }}$ genitor of dura type selected at Dabou; EH GP3: $3^{\text {rd }}$ progeny trial established at Ehania (Côte d'Ivoire); LM: La Mé (Côte d'Ivoire); LM 2 T: $2^{\text {nd }}$ genitor of tenera type selected in La Mé (Côte d'Ivoire); D: dura palm; T: tenera palm; P: pisifera palm.

\section{Copyrights}

Copyright for this article is retained by the author(s), with first publication rights granted to the journal.

This is an open-access article distributed under the terms and conditions of the Creative Commons Attribution license (http://creativecommons.org/licenses/by/4.0/). 